\begin{abstract}
George Steiner coined a concept that has been widely used in Literary Studies: the extraterritorial condition. The critic and philosopher developed it in Extraterritorial: Papers on Literature and the Language Revolution (1971), a work in which he reflects on notions such as criticism, language and estrangement. The "Language Revolution" in the subtitle refers to the profound crisis of language which occurred in Central Europe in the first third of the 20th century and that was experienced in the arts as the "failure of words". According to Steiner, the emergence of a linguistic pluralism and the "lack of a homeland" in some writers, such as Beckett, Nabokov or Borges, was part of this language revolution. Beyond the strictly linguistic field, today the extraterritorial category suggests global migratory movements and the constant displacement of the modern subject, in Steiner's words, as "a strategy of permanent exile".

In 1937 Samuel Beckett wrote his famous letter to Axel Kaun and also during this decade he was impressed by Fritz Mauthner's critique of human knowledge and his philosophy of language. In this sense, through these two threads, one can follow Beckett's tendency towards the "literatur des unworts" [sic], which will affect not only his works, but also his self-translation and bilingualism. Precisely in this period Beckett began to write in French to guarantee the effect of estrangement and radical insecurity provided by a language that is not one's own. His writing in French is austere and attenuated, thus assuming a voluntary linguistic exile for, as Beckett himself said, "le besoin d'être mal armé."
\end{abstract}

Keywords: Beckett, extraterritorial, Steiner, bilingualism, exile, language, silence

\title{
The "silence underlying all"
}

Beckett's writing frustrates any attempts of finding a coherent interpretation. The author was always reluctant to give clues about the meaning of his texts; the well-known phrase from the novel Watt "no symbols where none intended" is a good example of it. Yet, it is difficult to take Beckett's word, as his work is full of significant elements which seem to be constructed in a way that reflect and represent historical, philosophical and literary issues even though in a hermetic way.

Beckett always insisted that he had never formulated a thought about his own work. However, for many scholars the "German letter" is an explicit statement about his aesthetic creed in the 1930s. This typed 
letter ${ }^{1}$, dated July 9, 1937, was written to Axel Kaun, a German bookseller and publisher, who Beckett met on his journey to Germany during the winter of 1936-37.

If one of the major literary currents of the twentieth century begins, precisely, with a letter, the Letter of Lord Chandos, in which Hofmannsthal stands for silence and he diagnoses the crisis of language through the irrevocable and irreparable rupture of the relation between the words and the things they designate, Beckett expresses the same idea in this programmatic letter to which he will progressively adhere in his later works. The similarities with the Letter of Lord Chandos are evident in some excerpts:

It is indeed getting more and more difficult, even pointless, for me to write in formal English. And more and more my language appears to me like a veil which one has to tear apart in order to get to those things (or the nothingness) lying behind it. Grammar and style! To me they seem to have become as irrelevant as a Biedermeier bathing suit or the imperturbability of a gentleman. A mask." (Fehsenfeld 2009: 519)

Thus, writing art should penetrate the veil of words. Rupert Wood explains it as follows in his article on Beckett as an essayist:

Ordinary language, like any form of representation, is but a veil, but poetic language should be able to tear aside the veil and point to a space beyond representation, thus revealing words for what they are: merely a veil. What lies beyond this veil, though, remains unknown. It may be nothingness, and art in general may only be able to point to the opaque nature of representation rather than to any real object beyond it. (Wood 2006: 7)

For Beckett, the unmasking of the word is carried out by what he called the "Literatur des Unworts" [sic]. If at the beginning of his career-at the time he wrote this letter - this "literature" released from words wanted to be basically antirhetorical-in the sense of disregarding an antiquated, fossilised language-later it would eventually be a dismembered, dismantled writing based on pure negativity: the literature of falling silent.

In this letter, the Irish author considers that the artist has:

[...] To drill one hole after another into it [language] until that which lurks behind, be it something or nothing, starts seeping through - I cannot imagine a higher goal for today's writer. Or is literature alone to be left behind on that old, foul road long ago abandoned by music and painting? Is there something paralysingly sacred contained within the unnature of the word that does not belong to the elements of the other arts? Is there any reason why that terrifyingly arbitrary materiality of the word surface should not be dissolved, as for example the sound surface of Beethoven's Seventh Symphony is devoured by huge black pauses, so that for pages on end we cannot perceive it as other than a dizzying path of sounds connecting unfathomable chasms of silence? (Fehsenfeld 2009: 519)

1 The letter is kept at the Baker Memorial Library at Dartmouth College (Hanover, New Hampshire, USA). 
It is remarkable that one year after this letter Beckett began writing in French to ensure the effect of radical alienation, insecurity and estrangement that provides a language that is not one's own. Thus, he assumed, as well, a voluntary linguistic exile to avoid falling into the trap of this "crusty" word.

In addition, this text seems to incorporate the seed of announcing the intention to reach the final "a-verbal" stage as opposed to the overworked "adverbial" literature (Martínez-Lage 2004: 68) that he cultivated in his early writings. However, this approach has nothing to do with Joyce's work, which seems to be rather an "apotheosis of the word," as Beckett himself described it. In an interview by Israel Shenker, published at the New York Times in 1956, Beckett spoke of the author of Ulysses in the following terms:

Joyce is a superb manipulator of material-perhaps the greatest. He was making words do the absolute maximum of work. There isn't a syllable that's superfluous. The kind of work I do is one in which I'm not master of my material. The more Joyce knew the more he could. He's tending toward omniscience and omnipotence as an artist. I'm working with impotence, ignorance. I don't think impotence has been exploited in the past. There seems to be a kind of aesthetic axiom that expression is achievement-must be an achievement. My little exploration is that whole zone of being that has always been set aside by artists as some-thing unusable-as something by definition incompatible with art. (Graver and Federman 1999: 162)

Admittedly, even though we cannot deny Joyce's influence on Beckett's early works, there is a gulf between them concerning their attitudes towards language. If in Joyce's work words say everything, in Beckett's more mature writings, words cannot "say" anything, except their inability to say so. We must have in mind his "credo of an art of the nonfeasible" (Cohn 2001: 182), as Ruby Cohn puts it, in his dialogue with Georges Duthuit with reference to the text on Tal Coat: "The expression that there is nothing to express, nothing with which to express, nothing from which to express, no power to express, no desire to express, together with the obligation to express." (Beckett 1984: 139). According to Jenaro Taléns (Beckett 2001: 16), in Beckett's writing, words associate to display their fundamental ambiguity, based on showing two contradictory meanings. This place in which language stands, indistinguishable between two opposite positions, stresses the difficulty-not of multiplying the meaningas in Joyce's case, but to build a sense.

Of course, for the time being, one makes do with little. At first, it can only be a matter of somehow inventing a method of verbally demonstrating this scornful attitude vis-à-vis the word. In this dissonance of instrument and usage perhaps one will already be able to sense a whispering of the end-music or of the silence underlying all. (Fehsenfeld 2009: 515) 


\section{Extraterritorial Beckett}

George Steiner coined a concept that has been widely used in Literary Studies: the extraterritorial condition. The critic and philosopher developed it in Extraterritorial: Papers on Literature and the Language Revolution (1971), a work in which he reflects on notions such as criticism, language and estrangement. The "Language Revolution" in the subtitle refers to the profound crisis of language which occurred in Central Europe in the first third of the 20th century and was experienced in the arts as the "failure of words". According to Steiner, the emergence of a linguistic pluralism and the "lack of a homeland" in some writers, such as Beckett, Nabokov or Borges, was part of this language revolution. Beyond the strictly linguistic field, today the extraterritorial category suggests global migratory movements and the constant displacement of the modern subject, in Steiner's words, as "a strategy of permanent exile".

In his critical study Proust (1931), Beckett wrote: "There is no communication because there are no vehicles of communication" (1957: 47). During this decade Beckett was impressed by the reading of Fritz Mauthner's Beiträge zu einer Kritik der Sprache (Contributions to a critique of language), a 2,200-page work in 3 volumes written in 1901-1902. Mauthner, still today relatively unknown, was an Austrian philosopher and writer who developed a scepticism regarding the possibility of knowledge of the world through language ${ }^{2}$. According to John Pilling, "Mauthner in fact provided Beckett with the necessary ammunition to destroy all systems of thought whatever, even 'irrationalism"' (Pilling 2006: 128), and as Ben-Zvi states, "Mauthner also provided Beckett with a model: By placing language at the heart of the Critique, subsuming under it all knowledge, and then systematically denying its basic efficacy, Mauthner illustrates the possibility of using language to indict itself. The same linguistic centrality and nullity lie at the core of Beckett's work" (Ben-Zvi 1980: 183).

Mauthner's scepticism about language can be traced from the context of his time, the same as that of Hofmannsthal, and which implies the disappearance of a world: the Habsburg dynasty. Fritz Mauthner was born in Bohemia in 1849, in a German-speaking Jewish family. At the age of seven, he moved to Prague, which, together with Vienna and Budapest, was the cultural centre of the Habsburgs. Linda Ben-Zvi points to a certain parallelism between Mauthner and Kafka, who was born in the same city twenty-seven years later: two Jews who spoke German in a Czech-speaking society; the two of them studied Hebrew in Jewish schools, attended German institutes, studied law, admired Goethe and abhorred the rigid system and the hollow forms under which they were educated. Kafka de-

2 The influence of the philosopher on Beckett was already studied by renowned Beckett's scholars such as John Pilling, James Knowlson, David Hesla and Linda Ben-Zvi in the seventies and eighties, and has taken a new impulse in recent years with the studies by Dirk Van Hulle. 
fined his education as the "sawdust that thousands of jaws had chewed before him”, as Max Brod explained (Ben-Zvi 1980: 184). These are features that describe Steiner's category of extraterritorial writers.

Mauthner, who was influenced by Kant and Shopenhauer-like Beckett-considered that the thought of these philosophers did not analyse the basis on which this thought lay: language itself. This concern for articulation and philosophical methodology was part of a broad movement at the time in which Mauthner wrote: that of fin-de-siècle Vienna: the Vienna of Freud, Adolf Loos, Klimt or Karl Krauss, who defined this moment as "the proving ground for world destruction" (cited in Ben-Zvi 1980: 184).

How much did Beckett actually owe to Mauthner? Mauthner seems to have offered Beckett the philosophical verification of his scepticism about language which, together with the philosophical school of suspicion-with Nietzsche and Freud basically-deeply lies in the assumption that there is a lack of a direct relationship between things and the words they designate, that is, between language and reality. Nietzsche considers language as metaphorical, which means that reality is only partly apprehended through an indirect interpretation; Freud established languagelapsus, for instance-as a symptom of a contemporary split subject. For Beckett, becoming acquainted with these philosophical debates meant admitting the limits of language. Among all these argumentations that represented the linguistic turn, Mauthner also added the corruption of a fossilized, out-dated language, which no longer gave reasons for the representable world of his time. For Beckett this meant the obligation to write using a new language for literature.

There have been discussions about how Mauthner influenced Beckett and about when Beckett read Mauthner for the first time ${ }^{3}$. In a letter of 28 July 1978, Beckett told Linda Ben-Zvi that he had read Mauthner "for" Joyce in 1928-29 (Pilling 2006: 159); in another letter of 4 August 1978, addressed to Ruby Cohn, Beckett said he "skimmed through" Mauthner's Critique in 1932, when he was back in Paris and in contact with Joyce (Pilling 2006: 159). Richard Ellmann also mentions in his classic Joyce biography that Beckett read Mauthner in German to an almost blind Joyce in 1932, but, in a conversation with James Knowlson, Beckett said this information was inaccurate as he had read it himself, at the suggestion of Joyce (Ben-Zvi 1980: 198). ${ }^{4}$ However, our interest here is not in giving evidence about these biographical facts but in trying to find threads that can explain Beckett's radical and paradoxical attitude towards language.

It seems that Beckett's interest in the philosopher is not ephemeral. Apart from his typed notes on Mauthner's work and the pages written

3 Cf. the critical exchanges between Jennie Skerl and Linda Ben-Zvi in the "Forum" of the PMLA in 1980, as well as the polemic between Matthew Feldman with Garin Down (Samuel Beckett Today / Aujourd'hui 20, 2008, 375-399).

4 Eugene Jolas also seems to have played an important role in Joyce and Beckett's reading of Mauthner (See Pilling 2006: 160-161). 
down in the Whoroscope Notebook ${ }^{5}$, Beckett mentions Mauthner's name in his radio play for the BBC in 1976 Rough for Radio II and, in a conversation with Ben-Zvi in 1978, he said he still kept the three volumes from his library in a German edition of 1923 (Van Hulle; Nixon 2013: 162).

Mauthner develops in his treatise-and Beckett assumes-that his effort is doomed to fail even though he has things to say; thus, his commitment is to continue writing. In Three Dialogues with Georges Duthuit, Beckett feels "the obligation to express" what cannot be expressed, and the character Arsene in Watt (1953), when he speaks of what is unpronounceable or ineffable ${ }^{6}$, he says: "any attempt to utter or eff it is doomed to fail, doomed, doomed to fail" $(1959,62)$. The two authors place "fidelity to failure" at the centre of their work, as well as the recognition of the basic condition of human experience as something unknown and unknowable (Ben-Zvi 1980: 187).

Ben-Zvi indicates some analogies between the two authors regarding the treatment of language:

1. Thinking and talking are one activity

2. Language and memory are synonyms

3. All language is metaphor

4. There are no absolutes

5. The ego is contingent; it does not exist apart from language

6. Communication between men is impossible

7. The only language should be simple, simple language

8. The highest forms of a critique of language are laughter and silence

Analysing some of these aspects of Mauthner's philosophy and how Beckett incorporates them in his writing may help us understand some of the premises that have been stated so far ${ }^{7}$. The basis of Mauthner's critique lies in his insistence on the primacy of language in itself and not merely as a tool of expression or as a speculative medium. He considers that there is no thought outside language. Thus, by reducing all forms of knowledge to a form of speech, Mauthner reduces thought to linguistic habits; what is considered knowledge is a current, present use of language. Language, instead of offering an apprehension, illustrates how different men are in different societies and through different languages. We could say that it is

5 According to Pilling, in 1938 Beckett began writing poems directly in French for the first time. In one of these (the eighth of the Poèmes 38-39 as published "ainsi a-t-on beau") one line derives directly from entries from Kant, "which are to be found between and adjacent to the Mauthner material in the Whoroscope Notebook. [...] "ainsi a t-on beau" contains not only the reference to Kant but at least three separate phrases [...] derived directly from Mauthner, all of which are to be found in the Notebook just where one might expect to find them: close to the Kant entries" (2006: 163).

6 The verb "effari”, from Latin, meaning say, make known, utter.

7 Cf. Ben-Zvi: 1980, Pilling: 2006, Van Hulle: 2011, Weiler: 1970. 
a reflection and he affirms that there are as many logics as languages with different structures. If Beckett's concern in the '30s was the "Literatur des Unworts", thanks to Mauthner he understood that he could only show characters that spoke and whose words became signs, not of knowledge, but of a failure of knowledge (Ben Zvi 1980: 188).

In this sense, progressively, Beckett's characters do not stop talking, muttering the inability to say in the sense of knowing. The narrator in L'Innommable (The Unnamable) says of himself: "Je suis une grande boule parlante, parlant de choses qui n'existe pas ou qui existent peut-être, impossible of le savoir, la question n'est pas là..." (1953: 31). In the same way, the character in Malone meurt (Malone dies): “Au début je n'écrivais pas, je disais seulement. Puis j'oubliais ce que j'avais dit. Un minimum de mémoire est inindispensable, pour vivre vraiment" (1951: 55). Both Mauthner and Beckett speak of falling into silence, but not as a refuge. Beckett's characters speak as a necessary condition to live. Although words do not bring them closer to knowledge, they know language is the only thing they have got.

Following Ben-Zvi, for Mauthner, thinking and talking are synonyms and the source of this process is memory. Everything we knowall that our language consists of-are sensitive impressions; therefore, Mauthner bases language on the sensory experiences of memory, a word in which all possibilities of experience are included, as language is nothing more than the individual memory of that experience. In his essay Proust, Beckett shows the importance of memory in relation to the ability to express oneself. The modern subject, trapped in the habit, cannot access the encapsulated memories that are shown in those privileged moments in Proustian time. Like Mauthner, he considers that memory is distorted and not truthful. Thus, Beckett's characters try to access some images from a diffuse past that also distort the present time. Therefore, if memory only offers an approximation to the sensory images of the past, Mauthner believes that language can only be approximate or a metaphor for reality. Consequently, language creates images of images of images. If the senses are accidental, the modern subject can only obtain an approximation of reality, which implies the inexistence of certainties. For Mauthner there are no absolutes and for Beckett the colour of his character's reality is grey, given the impossibility of affirming or denying anything. They try to find the words that allow them to stop talking because they cannot overcome the limits of language.

Another important element is considering the modern subject as contingent. Beckett's characters have a "feeling" of themselves, but when they try to locate themselves, they do not find anything to identify this sensation with. The sense of being themselves is linked to a past, which they cannot completely reconstruct and which is, therefore, impossible to verify: "The I never finds a me", says Laura Barge, about these characters (cited in Ben-Zvi 1980: 193). This fact can be observed in the denial 
of some characters to say I. In Not I, the use of the narrator of the third person singular can be interpreted as a denial of the autotelic Cartesian subject, but also as the inability of the mouth to recognise the words that come out from it as theirs. If Beckett's characters were inarticulate, they would not suffer; but as they do not stop talking, they constantly feel that the words they use do not give voice to the split subject they perceive. Language is useful because of the need to communicate, for practical issues, but only a few who wish to be understood feel the inadequacy of it. In this sense, Beckett's characters talk about trivial things but they are aware that they use words to pass the time, to move silence away, like Winnie, in Happy Days, who talks because she wants to be heard.

Therefore, Mauthner articulates his Critique against the classical philosophical treatise, with its disposition to make words abstracted. A simple, non-rhetorical language is necessary, far from artifice and abstractions, which Beckett claimed in his "German Letter". It is necessary to keep a critical attitude with language and the highest form of language criticism is laughter and silence. Each laugh implies criticism, the best criticism, and silence is a goal that is never attainable at all.

\section{"Le besoin d'être mal armé"}

Through the "German Letter" and Mauthner's Critique of language, one can trace somewhat Beckett's tendency towards a "Literatur des Unworts" through laughter-a scornful attitude-and silence, which will affect his contemporary and also future texts, but probably the effects of Beckett's estrangement to language can go beyond the boundaries of his native tongue to the acquisition of French as a language of creation, self-translation and bilingualism.

In fact, the Irish author begins to write in French precisely to guarantee the effect of estrangement and radical insecurity provided by a language that is not his own. The change to French represents an important turning point in his writing. This transition allowed him to bare his style and create texts with very different characteristics in relation to the work previously written in English. His writing in French is austere, basic and simple, thus assuming a voluntary linguistic exile.

Beckett was a multilingual writer. He is one of the few authors who wrote practically all his work in two languages, English and French, and one of the very few who wrote in both languages simultaneously ${ }^{8}$. When Beckett self-translated his works, he would often change the new version, showing that it was impossible for him to repeat exactly the same in the translation process, which was also a creative one. In her essay "Samuel Beckett Self-Translator” (1961), Ruby Cohn analyses Beckett's translations

8 The authors that switched to French, for instance Arthur Adamov or Eugène Ionesco, having started writing in French, by and large stopped doing it in their native languages. 
of Murphy, the trilogy, Waiting for Godot and Endgame, and she was one of the first scholars to note that there were significant differences between the French and English texts, for example, that the French translation of Murphy helps to raise the comic tone.

The fact of opting for bilingualism was totally voluntary for Beckett. In any case, he did not have to do it for political, economic or religious reasons, as it would be the case of many exiled artists. In his essay "Extraterritorial", George Steiner introduces us to what he considers to be "extraterritoriality". Steiner takes up the ideas of Romanticism in national literatures and their conception of language to show us how twentieth-century literature and its most representative writers break with the precepts of linguistic and national unity. In the Romantic period, writers embodied the essence of their mother tongues, which represented the worldview of the nation. In this context, the idea of a "homeless" writer is strange, as it is unusual that he is not comfortable in the language in which he writes, that he feels marginalized or on the side-lines. Although European vernacular literature had been under the active influence of several languages for many centuries, this feeling of strangeness is recent, since it was a rule for seventeenth-century European elites to express themselves fluently in their own language and in Latin, French or both. Frequently, writers felt more comfortable in Latin or in French than in their mother tongue. Outstanding writers share this linguistic plurality: Heinrich Heine, Oscar Wilde, Samuel Beckett, Ezra Pound, Vladimir Nabokov, Jorge Luis Borges and Samuel Beckett. Thus, Steiner questions whether a single linguistic axis, that is, the mastery of a single language and, therefore, a deep connection to the homeland, is linked to poetic authority.

The idea of the writer who is a "master" of language and who feels at home in several languages is novel. As Steiner states:

But the writer as linguistic polymath $[\ldots]$ is something very new. That three figures of probable genius in contemporary fiction-Nabokov, Borges, and Beckett-should each have a virtuoso fluency in several languages, that Nabokov and Beckett should have produced major works in two or more utterly different tongues, is a fact of enormous interest. Its implications so far as the new internationalism of culture goes have hardly been grasped. Their performance [...] suggest that the modernist movement can be seen as a strategy of permanent exile. The artist and the writer are incessant tourists window-shopping over the entire compass of available forms (16-17).

In this regard, the Irish Beckettian scholar Alan Graham considers that Beckett's bilingualism has been one of the dominant topics over the last decades concerning Beckett's process of creation, but that it has "perhaps naturally, tended to obfuscate his complex relationship with English". The scholar deals with the idea of Beckett's "abandoning" English "to which he inexorably returned by considering the political and 
cultural pressures surrounding English in his native country", and with his critique of English in his early writings. According to Graham:

The author's misgivings concerning the facility of the language ("abstracted to death”) are read in light of a history of Irish, especially Anglo-Irish, anxiety in relation to the viability of English as a vessel for a national imaginary. [...] the 'language crisis' in Beckett ("not to know what it is the words it says say") is first a crisis of faith in the English language and one which recapitulates a distinctly Irish philological understanding of the 'death' of English. In addition, the formulation of a "literature of the unword" in the early career period is read in the shadow of the charged debate in the Irish Free State concerning 'official' language and a virulent nationalist language ideology proselytising the degeneracy of English. ${ }^{9}$

On this matter, in Beckett l'abstracteur. Anatomie d'une revolution littéraire (1997), Pascale Casanova has also controversially argued about Beckett changing into French. She presents Beckett as a writer who fights to avoid the "bardolâtres", the "antiquarians" of nationalism, as Beckett himself describe them in his critical essay of 1934 "Recent Irish Poetry" (Beckett 1984: 70), which were characterized by the romantic recovery of the Celtic world, embodied by W. B. Yeats. However, Casanova explains how Beckett also struggles to separate himself from the literary directions provided by Joyce's writing in order to achieve his own artistic independence. For Casanova, Beckett is not very Irish or, at least, she shows him as someone who reacts against "Irishness", which is reducible to a certain political vision of nationalism that Casanova denigrates. Thus, she presents a clearly cosmopolitan writer against his national inheritancenationalist, according to the French author's criterion-by rejecting this legacy and trying to dissolve it to integrate himself "à un autre univers plus doté en ressources littéraires" (Casanova 1999: 65), that is, Paris, "méridien de Greenwich de la littérature", the universal literary capital.

However, despite Casanova's attempts to turn this issue into a sociological matter, when Beckett was asked why he had adopted French for his writing, his answers were multiple and evasive. Since the publication of his letters, we have received some more evidence that does not move away from the questions we have dealt with in this paper. In some of these answers, he said he did not know why, and what is more that he did not know why he even wrote. In a series of conversations with Juliet Charles, Beckett explained that he had chosen French because it was a new language that had the perfume of strangeness, so it allowed him to escape the habits which were inherent in the use of his native tongue (Charles 1986: 27); he had also said that in French it was easier to write

9 Extract of the abstract of the plenary lecture "No Language but Theirs: Beckett, English, and the Language Politics of Ireland" (unpublished) that Alan Graham gave at the International Conference Samuel Beckett and Translation, University of Extremadura, Cáceres (Spain), 13 April 2018. 
without a style (Gessner, cited in Sindičić 2011: 164). On another occasion in 1948, he confessed, with a strong Irish accent, that he did it "Pour faire remarquer moi" (Craig 2011: 93). Both Leland de la Durantaye and Anne Beer consider the answer to be a playful joke: "Pour faire remarquer moi" can mean capturing attention, which Beckett facetiously achieves with the fact that an Irishman fails to utter a correct phrase in the language he adopts, even though by then Beckett had already completed extraordinary works in French. Another intriguing answer can be found in a letter of February 17, 1954 to Hans Naumann, a German translator.

Depuis 1945 je n'écris plus qu'en français. Pourquoi ce changement? It ne fut pas raisonné. Cela a été pour changer, pour voir, pas plus compliqué que cela, apparemment au moins. Rien à voir en tous cas avec les raisons que vous suggérez. Je ne considère pas l'anglais comme une langue étrangère, c'est bien ma langue. S'il en est une qui m'est parfaitement étrangère, c'est le gaélique. Vous pouvez me ranger dans la triste catégorie de ceux qui, s'ils devaient agir à bon escient, n'agiraient jamais. Ce qui m'empêche pas qu'il puisse y avoir, à ce changement, des raisons urgentes. Moi-même j'en entrevois plusieurs, maintenant qu'il est trop tard pour revenir en arrière. Mais j'aime mieux les laisser dans l'ombre. Je vous donnerai quand même une piste: le besoin d'être mal armé (Craig 2011: 461-62)

In it, Beckett claimed that switching to French was not deliberate but, at the same time, he offers a more specific clue: "pour le besoin d'être mal armé". Beckett alludes here to the "Literatur des Unworts", to the thread that he still maintains twenty years after the "German letter" and Mauthner's Critique: the need to be poorly armed, to adopt the language from a homeless, extraterritorial position. But here, once again, we can observe an ambiguity in the response, of course a playful one, which refers to the poet that was famous both for a reflection on language in literature and for the disappearance of elocution of the poetic voice: the need to be Mallarmé.

\section{BIBLIOGRAPHY}

Beckett, Samuel. Malone meurt. Paris: Ed. de Minuit, 1951.

Beckett, Samuel. L'innommable. Paris: Ed. de Minuit, 1953.

Beckett, Samuel. Proust. New York: Grove Press Ed., 1957.

Beckett, Samuel. Watt. New York: Grove Press Ed., 1959.

Beckett, Samuel. Disjecta. Miscellaneous Writings and a Dramatic Fragment.

Ed. and with an introduction by Ruby Cohn. New York: Grove Press Ed., 1984.

Beer, Anne. "Beckett's Bilingualism." The Cambridge Companion to Beckett. Ed. John Pilling. Cambridge: Cambridge University Press, 1994. 209221. 
Ben-Zvi, Linda. "Fritz Mauthner and the limits of language.” PMLA, Vol. 95, no 2, Mar. (1980). 183-200.

Casanova, Pascale. Beckett l'abstracteur. Anatomie d'une revolution littéraire. Paris: Éditions de Seuil, 1997.

Casanova, Pascale. La République mondiale des Lettres. Paris: Éditions du Seuil, 1999.

Cohn, Ruby. (1961): “Samuel Beckett, Self-Translator.” PMLA, Vol. 76, n 5, Dec. (1961). 613-621.

Cohn, Ruby. A Beckett Canon. Ann Arbor: The University of Michigan Press, 2001.

Craig, G., Fehsenfeld, M. D., Gunn, D., Overbeck, L. M., eds. The Letters of Samuel Beckett, 1929-1940. Vol. II. Cambridge: Cambridge University Press, 2011.

Durantaye, Leland de la. Beckett's Art of Mismaking. Cambridge, Massachusetts: Harvard University Press, 2016.

Fehsenfeld, M. D., Overbeck, L. M., eds. The Letters of Samuel Beckett, 19291940. Vol. I. Cambridge: Cambridge University Press, 2009.

Graver, L., Federman, R., eds. Samuel Beckett. The Critical Heritage. London and New York: Routledge. 1999.

Juliet, Charles. Rencontres avec Samuel Beckett. París: P.O.L., 1999.

Martínez-Lage, Miguel. "Samuel ante Samuel o Beckett antes de Beckett." Samuel Beckett, Deseos del hombre. Carta alemana. Segovia: La uNa RoTa, 2004.

Mauthner, Fritz. Contribuciones a una crítica del lenguaje. Translated by José Moreno Villa. Edited by Adan Kovacsics. Barcelona: Herder, 2001.

Pilling, John. "Beckett and Mauthner Revisited." Beckett after Beckett, S.E. Gontarski and A. Uhlmann, eds. Gainesville: University Press of Florida, 2006. 158-166.

Sindičić Sabljo, Mirna. "Beckett's Bilingualism, Self-Translation and the Translation of his Texts into the Croatian Language." The Journal of Linguistic and Intercultural Education (JoLIE), $\mathrm{n}^{\circ} 4$. Alba Iulia: Romania, (2011). 163-180.

Steiner, George. Extraterritorial. Papers on Literature and the Language Revolution. London: Faber and Faber, 1972.

Talens, Jenaro. “Introducción." Samuel Beckett, Detritus. Barcelona: Tusquets, 2001.

Van Hulle, Dirk. “'Eff it': Beckett and linguistic scepticism.”, Sofia Philosophical Review, 5:1 (2011). 210-227.

Van Hulle, Dirk, and Nixon, Mark, eds. Samuel Becktt's Library. Cambridge: Cambridge University Press, 2013.

Wood, Rupert. "An endgame of aesthetics: Beckett as essayist." The Cambridge Companion to Beckett, John Pilling, ed. Cambridge: Cambridge University Press, 1994. 1-16. 
Тереза Росел

\section{Самууел Бекети и линіввистиччки еїзил}

\section{Резиме}

Џорџ Стајнер је осмислио концепт који се много користи у проучавањима књижевности: стање екстратериторијалности. Тај критичар и филозоф га је елаборирао у свом делу Ексииратиерит̄оријално: Есеји о кюижевносиии и револуцији језика (1971), у коме се бави критиком, језиком и отуђењем. „Револуција језика" у поднаслову односи се на дубоку кризу језика која се појавила у Средњој Европи у првој трећини 20. века а која се одразила у уметностима као „неуспех речи“. Према Стајнеру, рађање језичког плурализма и „немање домовине“ код појединих писаца, као што су Бекет, Набоков или Борхес, био је део ове револуције језика. Иза строго лингвистичког поља, данас категорија екстратериторијалности сугерише глобална миграторна кретања и непрестано измештање модерног субјекта, према Стајнеровим речима, као „стратегије сталног егзила“. Самјуел Бекет је 1937. написао своје чувено писмо Акселу Кауну а, такође је, током те деценије био импресиониран критиком људског знања и филозофијом језика Фрица Маутнера. У том смислу, кроз ове две теме, можемо пратити Бекетову склоност ка "literatur des unworts" [sic], која ће утицати не само на његово дело, већ и на његово само-превођење и билингвизам. Управо у том периоду Бекет почиње да пише на француском како би постигао ефекат отуђења и радикалне несигурности коју изазива језик који није његов матерњи. Његово писање на француском језику је поједностављено и редуковано, обезбеђујући на тај начин језичко изгнанство због, како је то сам Бекет рекао, "le besoin d'être mal armé."

Кључне речи: Бекет, екстратериторијално, Стајнер, билингвизам, егзил, језик, тишина 